\title{
UJI AKTIVITAS ANTIBAKTERI TEH KOMBUCHA PROBIOTIK TERHADAP BAKTERI Escherichia coli dan Staphylococcus aureus
}

\author{
Ferry Effendi , Anna P. Roswiem, Ernie Stefani \\ Program Studi Farmasi Sekolah Tinggi Teknologi Industri dan Farmasi Bogor \\ Email :
}

\begin{abstract}
ABSTRAK
Teh kombucha telah banyak digunakan sebagai obat tradisional untuk menstabilkan metabolisme dan menawarkan racun sehingga dipercaya dapat melancarkan pencernaan.Probiotik berfungsi menyeimbangkan mikroflora usus yang dapat mencegah dan mengobati infeksi diare. Tujuan penelitian ini adalah untuk menguji aktivitas antibakteri serta menentukan Konsentrasi Hambat Minimum (KHM) dan Konsentrasi Bunuh Minimum (KBM) dari teh kombucha probiotik berbahan baku teh sencha terhadap Escherichia coli dan Staphylococcus aureus. Penelitian ini merupakan penelitian eksperimental laboratorium.Pengujian aktivitas antibakteri dilakukan dengan metode difusi agar.Penentuan KHM dan KBM dilakukan dengan metode dilusi padat.Hasil penelitian menunjukkan bahwa teh kombucha probiotik mempunyai aktivitas antibakteri terhadap Escherichia coli dan Staphylococcus aureus. Jumlah Bakteri Asam Laktat (BAL) pada teh kombucha probiotik sebesar $3,1 \times 10^{8} \mathrm{CFU} / \mathrm{ml}$, sehingga dapat dikategorikan sebagai minuman probiotik.Diameter zona hambat (DZH) tertinggi adalah terhadap bakteri Staphylococcus aureus yaitu terdapat pada konsentrasi $100 \%(\mathrm{DZH}=23,07 \mathrm{~mm})$. Diameter zona hambat terhadap bakteri Escherichia coli pada konsentrasi 100\% sebesar 21,76 mm. Namun diameter zona hambat Escherichia coli dan Staphylococcus aureus tersebut lebih rendah dibandingkan dengan diameter zona hambat kloramfenikol $30 \mu \mathrm{g} / \mathrm{ml}$ sebagai kontrol positif yaitu berturutturut sebesar 24,87 $\mathrm{mm}$ dan 26,25 mm. KHM dan KBM teh kombucha probiotik terhadap bakteri Escherichia coli terdapat pada konsentrasi 25\% dan 40\%. KHM dan KBM teh kombucha probiotik terhadap bakteri Staphylococcus aureus terdapat pada konsentrasi 25\% dan $35 \%$.
\end{abstract}

Kata kunci: Teh kombucha, probiotik, antibakteri, Escherichia coli, Staphylococcus aureus

\section{ANTIBACTERIAL ACTIVITY TEST OF PROBIOTIC KOMBUCHA TEA OF ESCHERICHIA COLIANDSTAPHYLOCOCCUS AUREUSBACTERIAL}

\begin{abstract}
Kombucha tea has been widely used as a traditional medicine to stabilize metabolism and neutralize poison, thus it is believed that it could expedite digestion. Probiotic is used to keep the balance of intestinal microflora, thus it may help prevent and treat infectious diarrhea. The objective of this study is to determine the antibacterial activity, and also determine the Minimum Inhibitory Concentration (MIC) and Minimum Bactericidal Concentration (MBC) of probiotic kombucha tea which made from sencha against Escherichia coli and Staphylococcus aureus. This study was experimental research laboratory. Antibacterial activity test was determined by using difussion method disc. The fixation of MIC and MBC was determined by using solid dilution method. The result showed that probiotic kombucha tea provides antibacterial potency on Escherichia coli and Staphylococcus aureus. The amount of Lactic Acid Bacteria (LAB) in probiotic kombucha tea was $3.1 \times 10^{8} \mathrm{CFU} / \mathrm{ml}$, so it was categorized as a probiotic drinks. The highest inhibition zone diameter was against Staphylococcus aureus bacteria, which in a concentration of $100 \%$ (23.07 mm). Inhibition zone diameter against Escherichia coli bacteria was in a concentration
\end{abstract}


of $100 \%(21.76 \mathrm{~mm})$. Nevertheless, the inhibition zone diameter of aforementioned Escherichia coli and Staphylococcus aureus was lower if compared with inhibition zone diameter of chloramphenicol $30 \mu \mathrm{g} / \mathrm{ml}$ as a positive control that was $24.87 \mathrm{~mm}$ and $26.25 \mathrm{~mm}$ respectively. MIC and MBC of probiotic kombucha tea against Escherichia coli bacteria was in a concentration of $25 \%$ and $40 \%$. MIC and MBC of probiotic kombucha tea against Staphylococcus aureus bacteria was in a concentration of $25 \%$ and $35 \%$.

Key words: Kombucha tea, Probiotic, Antibacterial, Escherichia coli, $\quad$ Staphylococcus aureus.

\section{PENDAHULUAN}

Bakteri Escherichia coli dan Staphylococcus aureus merupakan flora normal dalam tubuh manusia, tetapi keberadaannya pada makanan merupakan suatu cemaran (Swarbrick, 2004). Escherichia coli merupakan bakteri gram negatif yang dapat menyebabkan gangguan pada tubuh apabila Escherichia coli yang masuk ke tubuh berkisar $10^{6} \mathrm{sel} / \mathrm{ml}$. Gejala yang akan timbul adalah perut keram, diare, sakit kepala dan demam (Ray, 2005). Demikian pula, keracunan makanan dapat disebabkan oleh kontaminasi enterotoksin dari Staphylococcus aureus yang merupakan bakteri gram positif. Waktu timbulnya dari gejala keracunan biasanya cepat dan akut, tergantung pada daya tahan tubuh dan banyaknya toksin yang termakan. Jumlah toksin yang dapat menyebabkan keracunan adalah $1,0 \mu \mathrm{g} / \mathrm{gr}$ makanan. Gejala keracunan ditandai oleh rasa mual, muntah-muntah, dan diare yang hebat tanpa disertai demam (Ryan et al., 1994; Jawetz et al., 1995).

Umumnya pemberian obat-obat sintetik termasuk antibiotik dilakukan untuk mencegah infeksi diare, namun kebanyakan mengakibatkan resistensi. Pemilihan penggunaan obat tradisional saat ini cukup tinggi. Obat-obat tradisional tersebut tidak hanya digunakan dalam fase pengobatan saja, melainkan juga digunakan dalam fase preventif, promotif dan rehabilitasi. Salah satu obat tradisional yang cukup banyak digunakan dan terbukti bermanfaat adalah teh kombucha (Suprapti, 2003).

Teh kombucha merupakan produk minuman tradisional hasil fermentasi larutan teh dan gula dengan menggunakan starter mikroba kombucha (simbiosis bakteri dengan khamir) dan difermentasi selama 710 hari. Jenis mikroba utama yang berperan adalah Acetobacter xylinum dan dua khamir yaitu Saccharomyces cerevisiae danSaccharomyces ludwigii (Blanc, 2000). Zat-zat yang dihasilkan dari fermentasi kombucha menjadi benteng dari serangan bakteri patogen. Beberapa diantaranya berbagai macam vitamin (vitamin B kompleks, vitamin C), asam organik (asam asetat, asam folat, asam glukoronat, asam laktat) dan beberapa senyawa yang berfungsi sebagai antibiotik. Khasiat dari teh kombucha ini dapat mempengaruhi tubuh secara menyeluruh dengan menstabilkan metabolisme tubuh dan menawarkan racun (Naland, 2008).

Beberapa penelitian telah membuktikan bahwa teh kombucha juga memiliki khasiat sebagai berikut:

1. Penurunan kadar kolesterol total dalam darah (Winarni, 2010)

2. Sebagai peluruh batu ginjal (Anggriani, 2008)

3. Menurunkan kadar asam urat darah (Sriningsih et al., 2007)

4. Berfungsi sebagai antioksidan (Suhartatik dan Karyantina, 2008)

Probiotik adalah makanan suplemen berupa mikroba hidup yang menguntungkan manusia khususnya dalam keseimbangan mikroflora usus (Fuller, 1999). Probiotik secara langsung mampu membantu mikroflora yang berada di saluran pencernaan guna menghambat bakteri patogen yang dapat mengganggu saluran pencernaan. Probiotik juga dapat digunakan untuk membantu penderita lactose intolerance, dan mencegah penyakit diare (Tannock, 2005). 
Berdasarkan hal di atas maka perlu dilakukan penelitian terhadap aktivitas antibakteri teh kombucha dengan penambahan bakteri asam laktat yang berpotensi sebagai probiotik yang diperkirakan dapat bermanfaat sebagai antibakteri.

\section{METODE PENELITIAN}

Bahan : Teh hijau, starter kombucha, kultur isolate campuran bakteri probiotik Lactobacillus acidophilus, Bifidobacterium lactis dan Streptococcus thermophilus (1:1:1). Kultur biakan bakteri berasal dari PT Cisarua Mountain Dairy

\section{Cara Kerja}

Penelitian ini dilakukan dalam beberapa tahap yaitu (1) Pembuatan teh kombucha probiotik, (2) Analisis jumlah Bakteri Asam Laktat (BAL), (3) Uji aktivitas antibakteri dengan difusi agar, Penentuan nilai KHM dan KBM dengan dilusi padat dan (5) Pengukuran $\mathrm{pH}$.

\section{Pembuatan Teh Kombucha Probiotik}

Teh Kombucha dibuat sesuai prosedur dari Naland (2008) dengan cara teh sencha difermentasi dengan starter kombucha selama $\pm 7-10$ hari pada suhu $23-27^{\circ} \mathrm{C}$ atau setelah mencapai $\mathrm{pH} \pm 3$. Pembuatan teh sencha menggunakan $20 \mathrm{~g} / \mathrm{L}$ teh dengan konsentrasi gula pasir $10 \%$ sehingga dihasilkan teh sencha manis. Pembuatan teh kombucha probiotik dilakukan dengan menambahkan kultur isolat bakteri Lactobacillus acidophilus, Bifidobacterium lactis dan Streptococcus thermophilus dengan perbandingan 1:1:1 sebanyak 10\% ke dalam starter kombucha berbahan baku teh sencha, kemudian diinkubasi pada suhu $43^{\circ} \mathrm{C}$ selama 7 jam.

\section{Analisis Jumlah Bakteri Asam Laktat (Fardiaz, 1992)}

Teh kombucha probiotik dipipet sebanyak $1 \mathrm{~mL}$ dan dimasukkan ke dalam larutan $\mathrm{NaCl} \quad 0,85 \%$ sebanyak $9 \mathrm{ml}$, kemudian dihomogenkan menggunakan vortex, sehingga didapat pengenceran $10^{-1}$.
Selanjutnya pengenceran dibuat sampai $10^{-7}$ menggunakan larutan $\mathrm{NaCl} 0,85 \%$ sebanyak 9 mL. Pemupukan dilakukan pada pengenceran $10^{-5}$ sampai $10^{-7}$ dengan menggunakan media MRS (de Mann Rogosa Sharp) Agar dalam cawan petri. Pemupukan dilakukan duplo pada setiap pengenceran. Dilakukan pula pengujian terhadap teh kombucha (tanpa ada penambahan bakteri probiotik) sebagai kontrol negatif. Cawan petri selanjutnya diinkubasi pada suhu $35^{\circ} \mathrm{C}$ selama 48 jam kemudian dilakukan perhitungan jumlah koloni yang tumbuh dan dinyatakan dalam CFU/mL.

\section{Uji Aktivitas Antibakteri Dengan Difusi Agar}

Jenis penelitian ini adalah penelitian eksperimental laboratorium. Rancangan penelitian yang digunakan adalah rancangan acak lengkap (RAL). Pengujian ini dilakukan dengan 11 perlakuan dan setiap perlakuan terdiri atas 3 ulangan. Perlakuan yang dilakukan dalam penelitian ini adalah berbagai variasi konsentrasi teh kombucha probiotik, kontrol positif menggunakan kloramfenikol $30 \mu \mathrm{g} / \mathrm{ml}$ dan kontrol negatif menggunakan akuades (Samy dan Ignacimuthu, 2000; Kaur dan Arora, 2009; Naid et al., 2013).

Variasi pengenceran dengan cara melarutkan larutan teh kombucha probiotik dengan akuades steril. Dibuat beberapa variasi konsentrasi teh kombucha probiotik, meliputi konsentrasi $100 \%, 90 \%, 80 \%, 70 \%, 60 \%$, $50 \%, 40 \%, 30 \%$ dan $20 \%$.

Dilakukan pula pengujian terhadap teh kombucha (tanpa ada penambahan bakteri probiotik) sebagai kontrol negatif. Media NA (Nutrient Agar) sebanyak $15 \mathrm{~mL}$ dituang ke dalam cawan petri steril, diinokulasikan masing-masing suspensi bakteri uji sebanyak $0,1 \mathrm{~mL}$, dihomogenkan kemudian didiamkan beberapa saat hingga memadat. Kemudian pada permukaan media agar diletakkan kertas cakram, ditetesi masing-masing konsentrasi larutan kombucha probiotik yang telah ditentukan sebanyak 20 $\mu 1$. Pengujian juga dilakukan terhadap kontrol positif menggunakan kloramfenikol $30 \mu \mathrm{g} / \mathrm{mL}$ dan kontrol negatif dengan menggunakan akuades. 
Cawan petri yang sudah diberi perlakuan dengan berbagai konsentrasi, kontrol positif, dan kontrol negatif diinkubasi pada $35^{\circ} \mathrm{C}$ selama $24-48$ jam. Daerah bening di sekitar cakram menunjukkan adanya daerah hambatan bakteri. Diameter daerah hambat (DDH) diukur dalam satuan milimeter (mm) menggunakan jangka sorong. Dilakukan pula pengujian terhadap teh kombucha (tanpa ada penambahan bakteri probiotik) sebagai perbandingan.

Konsentrasi dimana larutan kombucha probiotik sudah tidak dapat menghambat pertumbuhan bakteri E.coli dan S.aureus digunakan sebagai acuan konsentrasi pada penentuan nilai KHM dan KBM. Pada uji aktivitas antibakteri kombucha probiotik dengan difusi agar ini menggunakan kontrol kontaminasi media dan kontrol pertumbuhan bakteri uji E.coli dan S.aureus.

\section{Penentuan Nilai KHM dan KBM Dengan Dilusi Padat}

Pada penentuan nilai KHM dan KBM dengan dilusi padat ini menggunakan dua macam kontrol, yaitu kontrol kontaminasi media dan kontrol pertumbuhan bakteri uji E.coli dan S.aureus (kontrol negatif).

Metode dilusi ini digunakan untuk menentukan konsentrasi minimum dari zat antibakteri yang dapat menghambat pertumbuhan bakteri. Metode ini dilakukan dengan cara mencampurkan zat pada media pembenihan yang kemudian diinokulasikan dengan bakteri lalu diinkubasikan. Hasil pengujian didapat dengan mengamati ada atau tidaknya pertumbuhan bakteri (Pratiwi, 2008).

\section{Uji Aktivitas Antibakteri dengan Dilusi Padat}

Diambil masing-masing bakteri uji dengan jarum ose, kemudian dibuat suspensi bakteri yang disetarakan kekeruhannya dengan larutan standar Mc Farland 0,5 (1,5 x $\left.10^{8} \mathrm{CFU} / \mathrm{mL}\right)$. Teh kombucha probiotik dengan kadar tertentu (sesuai dengan hasil pada uji sebelumnya) ditambahkan sebanyak $1 \mathrm{~mL}$ ke dalam suspensi bakteri (E.coli dan
S.aureus) masing-masing $0,1 \mathrm{ml}$. Selanjutnya dicampur rata dengan $15 \mathrm{ml}$ Nutrient Agar cair (suhu $45-50^{\circ} \mathrm{C}$ ), kemudian dituang dalam cawan petri secara cawan tuang. Diinkubasikan dalam suhu $35^{\circ} \mathrm{C}$ selama 24 48 jam.

Pertumbuhan bakteri dapat dilihat dari media yang menjadi keruh. Semakin subur pertumbuhan bakteri pada media, maka semakin keruh media tersebut. Pembacaan hasil daya antibakteri diberi penilaian dengan menggunakan notasi (++) untuk pertumbuhan yang tampak keruh, (+) agak keruh dan (-) jernih.

Kekeruhan masing-masing perlakuan dibandingkan dengan kontrol kontaminasi media dan kontrol pertumbuhan bakteri atau kontrol negatif.

Penentuan nilai KHM dan KBM dilakukan dengan metode streak plate (Goresan di cawan) dari hasil uji aktivitas antibakteri secara dilusi padat. Hasil uji yang digunakan adalah semua media yang memberikan kejernihan media secara visual. KHM adalah konsentrasi terkecil yang dapat menghambat bakteri, ditandai dengan E.coli dan S.aureus masih dapat tumbuh pada hasil goresan di cawan sedangkan KBM adalah konsentrasi terkecil yang dapat membunuh bakteri, ditandai dengan E.coli dan S.aureus sudah tidak dapat tumbuh pada hasil goresan di cawan yang menandakan masing-masing bakteri uji mati karena larutan uji dengan konsentrasi tersebut (McKane dan Kandel, 1996; Koneman et al., 1997).

\section{Pengukuran pH (AOAC, 2005)}

Teh kombucha probiotik sebanyak 25 $\mathrm{ml}$, diukur pHnya dengan $\mathrm{pH}$ meter yang telah dikalibrasi dengan larutan standar buffer $\mathrm{pH} 4,0$ dan $\mathrm{pH} 7,0$. Nilai $\mathrm{pH}$ diukur sebanyak 3 kali ulangan. Dilakukan pula pengujian terhadap teh kombucha (tanpa ada penambahan bakteri probiotik) sebagai kontrol negatif.

\section{HASIL DAN PEMBAHASAN}

Perhitungan nilai $\mathrm{CFU} / \mathrm{ml}$ dihasilkan dari perhitungan menggunakan metode pour plate. Perbedaan yang terlihat dalam tabel 1 
bahwa pada teh kombucha probiotik mengandung Bakteri Asam Laktat (BAL) yang tinggi $\left(3,1 \times 10^{8} \mathrm{CFU} / \mathrm{ml}\right)$ sedangkan teh kombucha (tanpa penambahan bakteri probiotik) mengandung Bakteri Asam Laktat (BAL) sebanyak 2,8 x $10^{2} \mathrm{CFU} / \mathrm{ml}$.

Asam laktat yang dihasilkan dari proses fermentasi teh kombucha berasal dari Bakteri Asam Laktat (BAL) yang dapat mensintesis laktosa menjadi asam laktat.

Pada proses fermentasi terjadi pemecahan senyawa kompleks seperti karbohidrat, protein dan lemak dengan bantuan mikroorganisme tertentu yang dapat menghasilkan asam organik, karbon dioksida, dan zat-zat lainnya. Proses fermentasi dapat menyebabkan perubahan sifat fisika dan kimia bahan pangan (Surono, 2004).

Teh kombucha tanpa ada penambahan bakteri probiotik belum dapat memenuhi syarat jumlah Bakteri Asam Laktat (BAL) untuk dikategorikan sebagai minuman probiotik karena jumlah Bakteri Asam Laktat (BAL) yang telah diteliti jauh di bawah syarat viabilitas Bakteri Asam Laktat (BAL) sebagai probiotik. Viabilitas Bakteri Asam Laktat (BAL) pada teh kombucha tanpa ada penambahan bakteri probiotik tidak terlalu baik karena jumlahnya tidak memenuhi syarat sebagai probiotik $\left(<10^{7}-10^{9} \mathrm{CFU} / \mathrm{ml}\right)$. Berdasarkan hal tersebut, maka dilakukan inokulasi Bakteri Asam Laktat (BAL) pada teh kombucha untuk meningkatkan jumlah Bakteri Asam Laktat (BAL).

Tabel 1. Hasil Analisis Jumlah Bakteri Asam Laktat (BAL)

\begin{tabular}{|c|c|c|c|c|c|c|}
\hline \multirow{3}{*}{ Sampel } & \multirow{3}{*}{ Ul } & \multicolumn{3}{|c|}{ Jumlah Koloni Pada } & \multirow{3}{*}{ CFU/ml } & \multirow{3}{*}{$\begin{array}{l}\text { Rata-rata } \\
\text { (CFU/ml) }\end{array}$} \\
\hline & & & gence & & & \\
\hline & & $10^{-5}$ & $10^{-6}$ & $10^{-7}$ & & \\
\hline \multirow{3}{*}{$\begin{array}{l}\text { Teh Kombucha } \\
\text { Probiotik }\end{array}$} & 1 & TBUD & 190 & 39 & $2,9 \times 10^{8}$ & \multirow{3}{*}{$3,1 \times 10^{8}$} \\
\hline & 2 & TBUD & 203 & 45 & $3,3 \times 10^{8}$ & \\
\hline & 3 & TBUD & 208 & 40 & $3,0 \times 10^{8}$ & \\
\hline \multirow{2}{*}{ Sampel } & Ul & \multicolumn{3}{|c|}{ Pengenceran } & & Rata-rata \\
\hline & UI & $10^{-0}$ & $10^{-1}$ & $10^{-2}$ & $\mathrm{CFU} / \mathrm{ml}$ & (CFU/ml) \\
\hline \multirow{3}{*}{ Teh Kombucha } & 1 & 243 & 23 & 1 & $2,4 \times 10^{2}$ & \multirow{3}{*}{$2,8 \times 10^{2}$} \\
\hline & 2 & 265 & 32 & 3 & $2,9 \times 10^{2}$ & \\
\hline & 3 & 282 & 34 & 3 & $3,1 \times 10^{2}$ & \\
\hline
\end{tabular}

Ket : U1 : Ulangan

TBUD : Terlalu Banyak Untuk Dihitung (>300 CFU/ml)

\section{Hasil Uji Aktivitas Antibakteri Teh Kombucha Probiotik dengan Difusi Agar}

Hasil pengukuran Diameter Zona Hambat (DZH) dengan menggunakan metode difusi agar dapat dilihat pada gambar 1. Hasil pengukuran menunjukkan bahwa semakin besar konsentrasi teh kombucha probiotik yang digunakan, maka semakin besar pula Diameter Zona Hambat (DZH) pertumbuhan bakteri yang terbentuk, karena pada konsentrasi yang lebih besar makin banyak zat aktif yang terdapat di dalam teh kombucha probiotik. Teh kombucha probiotik tidak lebih baik dari kloramfenikol $30 \mu \mathrm{g} / \mathrm{ml}$ dalam menghambat pertumbuhan bakteri E.coli dan S.aureus.
Hasil Penentuan nilai KHM dan KBM dengan Dilusi Padat

Untuk memastikan nilai KHM dan KBM, maka dilakukan penegasan hasil dengan metode streak plate pada semua konsentrasi yang menghasilkan media yang jernih.

Hasil pengamatan pertumbuhan bakteri E.coli dapat dilihat pada Tabel 2. Hasil pengamatan pada konsentrasi 25, 30, dan $35 \%$ masih ada pertumbuhan bakteri, sedangkan pada konsentrasi 40, 45, 50, 60,70 dan $100 \%$ tidak terlihat adanya pertumbuhan bakteri. Maka dapat disimpulkan bahwa KHM dari teh kombucha probiotik terhadap bakteri E.coli adalah 25\% dan KBM dari teh kombucha probiotik terhadap bakteri E.coli 
adalah $40 \%$. Hasil uji aktivitas antibakteri dapat dilihat pada tabel 2 .

Hasil pengamatan pertumbuhan bakteri S.aureus dapat dilihat pada tabel 3. Hasil pengamatan pada konsentrasi 25 dan $30 \%$ masih ada pertumbuhan bakteri, sedangkan pada konsentrasi $35,40,45,50,60,70$ dan
$100 \%$ tidak terlihat adanya pertumbuhan bakteri. Maka dapat disimpulkan bahwa KHM dari teh kombucha probiotik terhadap bakteri S.aureus adalah 25\% dan KBM dari teh kombucha probiotik terhadap bakteri S.aureus adalah $35 \%$.

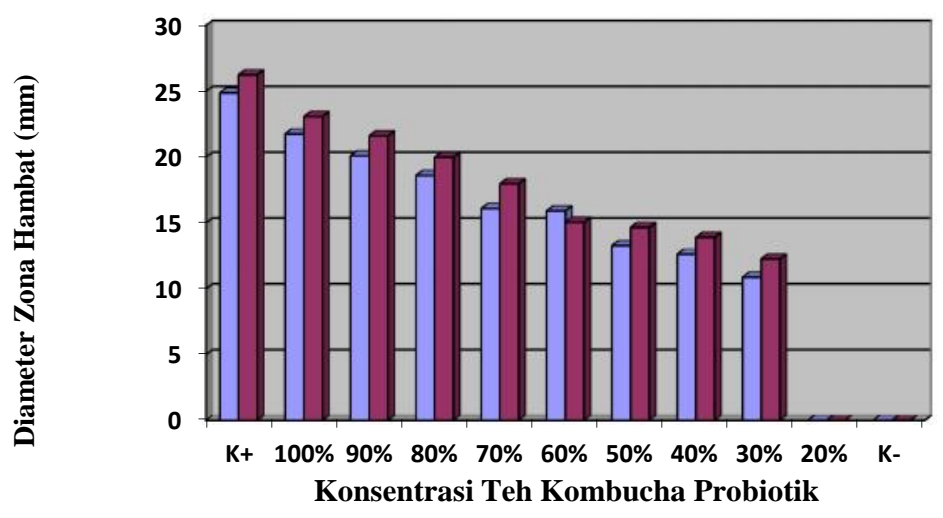

口E.coli

口S.aureus

Gambar 1. Perbandingan Diameter Zona Hambat Teh Kombucha Probiotik Terhadap E.coli dan S.aureus

Tabel 2. Hasil Uji Aktivitas Antibakteri terhadap E.coli dengan Dilusi Padat

\begin{tabular}{|c|c|c|c|}
\hline \multirow{2}{*}{ Konsentrasi } & \multicolumn{3}{|c|}{$\begin{array}{c}\text { Pertumbuhan Bakteri / } \\
\text { Kekeruhan }\end{array}$} \\
\hline & $\begin{array}{c}\text { Ulangan } \\
1\end{array}$ & $\begin{array}{c}\text { Ulangan } \\
2\end{array}$ & $\begin{array}{c}\text { Ulangan } \\
3\end{array}$ \\
\hline Kontrol & & & \\
\hline Positif & - & - & - \\
\hline $100 \%$ & - & - & - \\
\hline $70 \%$ & - & - & - \\
\hline $60 \%$ & - & - & - \\
\hline $50 \%$ & - & - & - \\
\hline $45 \%$ & - & - & - \\
\hline $40 \%$ & - & - & - \\
\hline $35 \%$ & - & - & - \\
\hline $30 \%$ & - & - & - \\
\hline $25 \%$ & - & - & - \\
\hline $20 \%$ & ++ & ++ & ++ \\
\hline $\begin{array}{l}\text { Kontrol } \\
\text { Negatif }\end{array}$ & ++ & ++ & ++ \\
\hline
\end{tabular}

Keterangan : ++ : keruh, + : agak keruh, - : jernih 
Tabel 3. Hasil Uji Aktivitas Antibakteri terhadap S.aureus dengan Dilusi Padat

\begin{tabular}{cccc}
\hline & \multicolumn{3}{c}{ Pertumbuhan Bakteri / } \\
Konsentrasi & \multicolumn{3}{c}{ Kekeruhan } \\
\cline { 2 - 4 } & Ulangan & Ulangan & Ulangan \\
& 1 & 2 & 3 \\
\hline Kontrol & - & - & - \\
Positif & - & - & - \\
$100 \%$ & - & - & - \\
$70 \%$ & - & - & - \\
$60 \%$ & - & - & - \\
$50 \%$ & - & - & - \\
$45 \%$ & - & - & - \\
$40 \%$ & - & - & - \\
$35 \%$ & - & - & - \\
$30 \%$ & - & - & - \\
$25 \%$ & - & + & + \\
$20 \%$ & + & + & + \\
Kontrol & ++ & ++ & ++ \\
Negatif & ++
\end{tabular}

Keterangan : ++ : keruh, + : agak keruh, - : jernih

Tabel 4. Hasil Uji pH

\begin{tabular}{cccc}
\hline \multicolumn{3}{c}{ Ulangan ke- } & \multirow{2}{*}{ Rata-rata } \\
\cline { 1 - 3 } $\mathbf{1}$ & $\mathbf{2}$ & $\mathbf{3}$ & \\
\hline 3.05 & 3.05 & 3.09 & 3.06 \\
\hline
\end{tabular}

Nilai $\mathrm{pH}$ teh kombucha dan teh kombucha probiotik ini memenuhi tingkat keasaman standar dari teh kombucha yaitu 2.7-3.2 (Naland, 2008). Pada umumnya semakin meningkatnya kandungan asam suatu bahan maka nilai $\mathrm{pH}$ akan semakin turun. Penurunan $\mathrm{pH}$ teh kombucha diduga disebabkan oleh peningkatan konsentrasi zatzat asam selama proses fermentasi. Zat asam yang terlarut akan melepaskan proton yang menyebabkan penurunan $\mathrm{pH}$ (Suhiman, 2012).

Penurunan $\mathrm{pH}$ terjadi karena selama proses fermentasi khamir dan bakteri mensintesis sukrosa menjadi asam-asam organik, seperti asam asetat, asam glukonat dan beberapa asam organik lainnya, sehingga dengan peningkatan konsentrasi asam-asam organik tersebut mengakibatkan penurunan $\mathrm{pH}$ pada medium fermentasi. Penurunan lebih lanjut pada $\mathrm{pH}$ teh kombucha probiotik dikarenakan pada saat proses inkubasi bakteri probiotik $10 \%$ ke dalam teh kombucha, terjadi proses fermentasi oleh bakteri probiotik yang menghasilkan asam laktat sehingga terjadi penurunan $\mathrm{pH}$ mencapai 3.06.

\section{SIMPULAN}

Berdasarkan hasil penelitian dapat disimpulkan bahwa teh kombucha probiotik memiliki aktivitas antibakteri terhadap pertumbuhan bakteri E.coli dan S.aureus. Teh kombucha probiotik memiliki nilai KHM sebesar $25 \%$ terhadap bakteri E.coli dan S.aureus serta memiliki nilai KBM sebesar $40 \%$ terhadap bakteri E.coli dan sebesar 35\% terhadap bakteri S.aureus.

\section{DAFTAR PUSTAKA}

[AOAC] Association of Official Analytical Chemist. 2005. Official Methods of Analysis. $\quad$ Ed ke-14. Arlington: Association of Official Analytical Chemist.

Anggriani, Y.D. 2008. Pengaruh Pemberian Teh Kombucha Dosis Bertingkat Per Oral Terhadap Gambaran Histologi Ginjal Mencit BAL B/C[skripsi]. Semarang: $\quad$ FK Universitas Diponegoro.

Blanc, P.J. 2000. Characterization Of The Tea Fungus Metabolites. www.kombucha-research.com[09 Agustus 2013]. 
Fuller, R. 1999. Probiotics for Farm Animals. Tannock, G.W., editor. New York: Horizon Scientific Press.

Jawetz, E. et al. 1995. Mikrobiologi Kedokteran. Edisi ke-20. Nugroho, R.F.Maulany, penerjemah; Jakarta : Penerbit Buku Kedokteran EGC. hlm 211-215.

Kaur, G.J., Arora, D.S. 2009. Antibacterial Activity of Some Indian Medicinal plants. J Nat Med 61(1): 313-317.

Naid, T., Kasim, S., Marzuki, A. Produksi Antibiotika Secara Fermentasi dari Biakan Mikroorganisme Simbion Rumput Laut Eucheuma cottonii. Majalah Farmasi dan Farmakologi 17(3): 61-68.

Naland, H. 2008. Kombucha, Teh Dengan Seribu Khasiat. Jakarta: AgroMedia Pustaka.

Pratiwi, S.T. 2008. Mikrobiologi Farmasi. Jakarta : Erlangga. hlm 188-191.

Ray, B. 2005. Fundamental Food Microbiology. $3^{\text {rd }}$ ed. Florida: CRC Press LLC.

Ryan, K.J. et al. 1994. Medical Microbiology An Introduction to Infectious Diseases. $\quad 3^{\text {rd }}$ ed. Connecticut: Appleton \& Lange. hlm 254.

Samy, R.P., Ignacimuthu, S. 2000. Antibacterial Activity of Some Folklore Medicinal Plants Used by Tribals in Western Ghats of India. Journal of Ethnopharmacology 69(1): 63-71.

Sriningsih, S., Sari, P., Priyanto. 2007. Pengaruh Pemberian Teh Kombucha Terhadap Kadar Asam Urat Darah Tikus Putih Jantan. Jurnal Bahan Alam Indonesia ISSN 1412-2855 6(3): 118-121.

Suhartatik, N., Karyantina, M. 2008. Kombucha Dengan Variasi Kadar Gula Kelapa Sebagai Sumber Karbon. Jurnal Teknologi dan Industri Pangan 19(2): 165-169.

Suhiman, S. 2012. Teh Kombucha Sebagai Minuman Fungsional Untuk Meningkatkan Daya Tahan Tubuh. Di dalam : Hadipoentyanti, E., editor.
Warta Penelitian dan Pengembangan Tanaman Industri; Bogor, Agustus 2012. Bogor: Balitro. Hlm 26 - 30.

Suprapti, M.L. 2003. Teh Jamsi dan Manisan Nata Berkhasiat Obat. Jakarta: Penerbit Kanisius.

Surono, I.S. 2004. Probiotik Susu Fermentasi dan Kesehatan. Jakarta : PT. Tri Cipta Karya.

Swarbrick, J. 2004. Microbial Contamination Control in the Pharmaceutical Industry. Volume 142. New York : Marcel Dekker Inc.

Tannock, G.W. 2005.Probiotics and Prebiotics: Scientific Aspects. New York: Horizon Scientific Press. hlm. 43.

Winarni, D. 2010. Pengaruh Pemberian Teh Kombucha Terhadap Penurunan Kadar Kolesterol Total dalam Darah[skripsi]. Surakarta: FK-UNS. 
